\title{
SOLID PHASE EXTRACTION OF TRACE AMOUNTS OF ZINC AND CADMIUM IONS USING PERLITE AS A SUPPER SORBENT
}

\author{
Mahmoud Roushani ${ }^{1}$, Yar Mohammad Baghelani ${ }^{1}$, ShahryarAbbasi ${ }^{1}$, Sayed Zia Mohammadi ${ }^{2 *}$ \\ and Maryamosadat Mavaei ${ }^{1}$ \\ ${ }^{1}$ Department of Chemistry, Faculty of Sciences, Ilam University, Ilam, Iran \\ ${ }^{2}$ Department of Chemistry, Payame Noor University, Tehran, Iran
}

(Received June 30, 2014; revised May 20, 2016)

\begin{abstract}
A novel method using a packed column with perlite as a new sorbent has been developed for preconcentration of trace amounts of zinc and cadmium prior to their determination by flame atomic absorption spectrometry. Several factors that may be affected on the solid phase extraction (SPE) process, such as $\mathrm{pH}$, sample volume, flow rate, volume and concentration of eluent were studied and optimized. Linearity was maintained between $0.001-0.1 \mu \mathrm{g} \mathrm{mL}^{-1}$ for zinc, and $0.001-0.3 \mu \mathrm{g} \mathrm{mL}^{-1}$ for cadmium. Detection limits based on $3 \mathrm{~S}_{\mathrm{b}}$ for zinc and cadmium were 1.8 and $1.6 \mathrm{ng} \mathrm{mL} \mathrm{mL}^{-1}$, respectively. The relative standard deviations of eight replicate measurements of $0.02 \mu \mathrm{g} \mathrm{mL} \mathrm{mL}^{-1}$ of zinc and $0.05 \mu \mathrm{g} \mathrm{mL} \mathrm{m}^{-1}$ of cadmium ions were $2.1 \%$ and $1.8 \%$, respectively. Finally, the developed method was successfully applied to extraction and determination of the zinc and cadmium ions in the water and food samples and satisfactory results were obtained.
\end{abstract}

KEY WORDS: Solid phase extraction, Zinc determination, Cadmium determination, Preconcentration, Perlite

\section{INTRODUCTION}

The contamination by heavy metals from various environmental sources including natural waters is a great concern nowadays. Water pollution by heavy metals is causing serious ecological problems in many parts of the world [1].

Flame and/or graphite furnace atomic absorption spectrometry, inductively coupled plasmaoptical emission spectrometry, inductively coupled plasma-mass spectrometry and electro analytical techniques are the main instrumental techniques for the determination trace amounts of heavy metal ions [2-5]. The presence of trace heavy metals lower than the detection limits of these instrumental techniques is one of the main problems [6-8]. To solve this problem, an effective extraction and preconcentration method is necessary. Preconcentration techniques including liquid-liquid extraction, cloud point extraction, coprecipitation, membrane filtration and solid phase extraction (SPE) are generally used by the researchers around the world [9-14].

In the last two decades, the SPE has gained rapid acceptance [15]. SPE is an attractive technique based on the use of a sorbent that retains the analytes. The analytes are eluted from the sorbent using a suitable solvent. SPE is an attractive technique that reduces consumption and exposure to solvent, disposal costs and extraction time [16]. Recently, SPE was successfully utilized for the preconcentration and separation of trace metal ions from different matrices [1727]. Adsorption by low-cost adsorbents has been successfully applied to remove heavy metals from aqueous solutions. Perlite is generally chemically inert and has a $\mathrm{pH}$ of approximately 7. Perlite is very cheap and easily existing in Iran markets. The cost of perlite is less than US\$ 0.2 per $\mathrm{kg}$ in Iran. This could make it used as a viable candidate for extracting metals such as zinc and cadmium. The chemical composition of the perlite found in Iran is given in Table 1. The aim of this work was combination solid phase extraction with flame atomic absorption spectrometry and proposes a new method for separation, preconcentration and determination of

${ }^{*}$ Corresponding author. E-mail: szmohammadi@yahoo.com 
trace amounts of zinc and cadmium ions in water and food samples. To the best of our knowledge, perlite as a new sorbent was never used before for this application.

Table 1. The chemical composition of perlite.

\begin{tabular}{|l|c|}
\hline Constituent & Percentage present \\
\hline $\mathrm{SiO}_{2}$ & $71-75$ \\
\hline $\mathrm{Al}_{2} \mathrm{O}_{3}$ & $12.5-18$ \\
\hline $\mathrm{Na}_{2} \mathrm{O}$ & $2.9-4.0$ \\
\hline $\mathrm{K}_{2} \mathrm{O}$ & $4.0-5.0$ \\
\hline $\mathrm{CaO}$ & $0.5-2.0$ \\
\hline $\mathrm{Fe} \mathrm{O}_{3}$ & $0.1-1.5$ \\
\hline $\mathrm{MgO}$ & $0.03-0.5$ \\
\hline $\mathrm{TiO}_{2}$ & $0.03-0.2$ \\
\hline $\mathrm{MnO}_{2}, \mathrm{FeO}, \mathrm{BaSO}_{3}$, & $0.0-0.1$ \\
\hline
\end{tabular}

\section{EXPERIMENTAL}

\section{Instrumentation}

A CTA2000 atomic absorption spectrometer (Chem. Tech. Analytical, United Kingdom) equipped with zinc and cadmium hollow cathode lamp was used for absorbance measurements at wavelengths of 213.9 and $228.8 \mathrm{~nm}$, respectively. The instrumental parameters were adjusted according to the manufacturer's recommendations. The suggested flow rate for nebulizer ranges between 4.0 and $6.0 \mathrm{~L} \mathrm{~min}^{-1}$. A nebulizer flow rate of $5.0 \mathrm{~L} \mathrm{~min}^{-1}$ was used for all experiments. A Metrohm $827 \mathrm{pH}$ meter was used for $\mathrm{pH}$ measurements. Funnels-tipped glass tube $(5 \times 100$ $\mathrm{mm}$ ) equipped with stopcock was used as column for the preconcentration purposes.

\section{Reagents and solutions}

All the reagents were analytical grades and obtained from Merck (Darmstadt, Germany). The laboratory glassware was kept overnight in $1.4 \mathrm{M} \mathrm{HNO}_{3}$ solution. Before using, the glassware was washed with double distilled water and dried. Stock solutions of $\mathrm{Zn}(\mathrm{II})$ and $\mathrm{Cd}(\mathrm{II})$ ions at a concentration of $1000 \mu \mathrm{g} \mathrm{mL}^{-1}$ were purchased from Merck. The working reference solutions were obtained daily by stepwise dilution from stock solution with double distilled water. Phosphate buffer solution $\left(\mathrm{H}_{2} \mathrm{PO}_{4}{ }^{-} / \mathrm{HPO}_{4}{ }^{2-}\right)$ was prepared by mixing of appropriate volumes of $0.2 \mathrm{M}$ potassium dihydrogen phosphate and disodium hydrogen phosphate solutions for $\mathrm{pH} 10$. Methanol, ethanol and acetic acid with the highest purity available were purchased from Merck. Nitrate salts of aluminum, chromium, rhodium, lead, cobalt, manganese, iron, nickel, copper, magnesium, calcium and silver with highest purity available were obtained from Merck and used without any further purification. Solution of alkali metal salts $1 \%(\mathrm{w} / \mathrm{v})$ and various metal salts $0.1 \%(\mathrm{w} / \mathrm{v})$ were used to study the interference of ions.

\section{Perlite and column preparation}

Perlite (50 meshes ASTM.E. 11. Damavand-Iran) was used as the supporting material. A small amount of glass wool was placed in the end of column (100 mm length and $5 \mathrm{~mm}$ i.d.), which is equipped with stopcock, to prevent loss of the sorbent during sample loading. Then, the column was packed with $70 \mathrm{mg}$ of the perlite. The bed height of the perlite in the column was approximately $5 \mathrm{~mm}$. It was conditioned by passing $2 \mathrm{~mL}$ buffer solution with a flow rate of 1 
$\mathrm{mL} \min ^{-1}$ to wet and convert perlite to a more colloidal form with higher surface area prior to use.

Analytical procedure

Column procedure was applied for the preconcentration process. Twenty five $\mathrm{mL}$ solution containing $1.0 \mu \mathrm{g}$ of zinc and cadmium, and $2 \mathrm{~mL}$ of phosphate buffer $(\mathrm{pH} \mathrm{10.0)}$ were passed through the column at a flow rate of $2 \mathrm{~mL} \mathrm{~min}^{-1}$. The retained metal ions were eluted from the column with $3 \mathrm{~mL}$ of $1 \mathrm{M} \mathrm{HCl}$ in ethanol and the solution was aspirated into an air-acetylene flame for determination of zinc and cadmium. A blank solution was also run under the same conditions without adding the analyte ions.

\section{Preparation of samples}

Tap water and well water samples were collected in acid leached polyethylene bottles (one liter). Tap water sample was collected from Ilam (Ilam, Iran). The well water sample was collected from our university (Ilam, Iran). The only pretreatment applied was acidification to $\mathrm{pH}$ 2.0 with nitric acid, which was performed immediately after collection, in order to prevent adsorption of the metal ions on the flask walls. The samples were filtered before analyses through a cellulose membrane of $0.45 \mu \mathrm{m}$ pore size (Millipore).

Two certified reference materials (CRMs) furnished by the National Institute for Environment Studies (NIES) No. 7 Tea Leave and NIES No. 1 Pepperbush were analyzed. Approximately 1.0 g NIES No. 1 and 1.0 g NIES No. 7 were weighted accurately into two Teflon cup and dissolved in $10 \mathrm{~mL}$ concentrated nitric acid with heating on a water bath. The solutions were cooled, diluted and filtered by using Whatman Glass Microfiber Filter Paper Grade 6. The filtrates were made to $100.0 \mathrm{~mL}$ with de-ionized water in two calibrated flasks. An aliquot of the sample solution was taken individually, and analyte ions were determined by the analytical procedure.

Approximately $5.0 \mathrm{~g}$ of dry rice, spaghetti, bread and black tea samples were taken in four different beakers and dissolved in $10 \mathrm{~mL}$ concentrated nitric acid and perchloric acid (3:1) with heating on a water bath. The solutions were cooled, diluted and filtered (Whatman Glass Microfiber Filter Paper Grade 6). The filtrates were made to $100.0 \mathrm{~mL}$ with de-ionized water in four calibrated flasks.

\section{RESULTS AND DISCUSSION}

In this study, the optimum sorption and desorption properties of perlite for zinc and cadmium ions were studied by using column method. Quantitative recovery was obtained for zinc and cadmium without using a chelating agent. The effect of some analytical parameters such as $\mathrm{pH}$, amount of adsorbent, type, concentration and volume of eluent solution, flow rate of sample solution, and volume of sample solution on the recovery of the analyte ions have been investigated. Each experiment was repeated in triplicate, and the averaged values are given as the results.

\section{Effect of $p H$}

Since the $\mathrm{pH}$ of the aqueous sample solutions is an important analytical factor in SPE, the adsorption of $\mathrm{Zn}(\mathrm{II})$ and $\mathrm{Cd}(\mathrm{II})$ by perlite was investigated at the $\mathrm{pH}$ range of 3-11. The $\mathrm{pH}$ of sample solutions was adjusted by $0.1 \mathrm{M} \mathrm{NaOH}$ or $0.1 \mathrm{M} \mathrm{HNO}_{3}$. The results are shown in Figure 1. Figure 1 reveals that the adsorption efficiency of the analytes improved dramatically and reached maximum at $\mathrm{pH} 10$. The distribution of active sites on the surface of metal oxides can be influenced by $\mathrm{pH}$ solution [28]. At high $\mathrm{pHs}$, the $\mathrm{OH}^{-}$on the sorbent can adsorbed cations,

Bull. Chem. Soc. Ethiop. 2016, 30(2) 
but, in the low pHs, the surface charge is neutralized and $\mathrm{OH}^{-}$is removed from the surface, therefore the adsorption of cations is decreased onto metal oxides. Accordingly, further studies were done at $\mathrm{pH} 10$ using a $0.2 \mathrm{M}$ phosphate buffer solution. The volume of buffer was also studied. The results were showed that addition of $1-4 \mathrm{~mL}$ of buffer did not have any effect on the extraction of the analyte ions. Therefore, $2 \mathrm{~mL}$ phosphate buffer solution was used in all subsequent experiments.

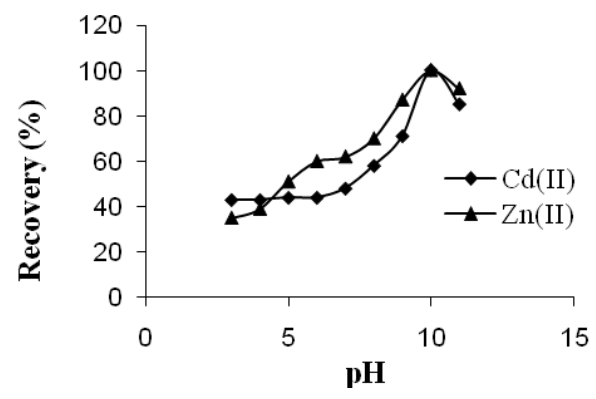

Figure 1. Effect of pH: Conditions: analyte, $1.0 \mu \mathrm{g} \mathrm{Zn}(\mathrm{II})$ and $1.0 \mu \mathrm{g} \mathrm{Cd}(\mathrm{II})$; sorbent, $70 \mathrm{mg}$;

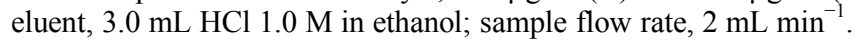

\section{Effect of amount of the sorbent}

The amount of sorbent is another important parameter that affects the recovery. A quantitative retention is not obtained when the amount of sorbent is less. At low amounts of sorbent, active sites for sorption of metal ions is low. At higher amounts of sorbent, however, the available sites become sufficient for complete sorption of metal ions. For this purpose, different amounts of the sorbent (10-100 mg) were examined. The results showed that when the sorbent quantity was greater than $40 \mathrm{mg}$, quantitative recoveries of the metal ions were obtained. With respect to these results, $70 \mathrm{mg}$ of perlite was chosen for further experiments.

\section{Selection of the best eluent and optimization of its concentration and volume}

In order to choose the most effective eluent, the effect of various acidic solutions on desorption of the analyte ions were studied under the optimum conditions. The results (Table 2) showed complete desorption for all metal ions were obtained with $\mathrm{HCl}$ and $\mathrm{HNO}_{3}$ in ethanol and methanol. Methanol reduces the surface tension of solution, so that smaller droplets produced and more atoms at the same time into the flame, and as a result a greater number of atoms. Since, methanol is poisonous; therefore $\mathrm{HCl}$ in ethanol was selected as eluent for further applications. After selection of $\mathrm{HCl}$ in ethanol as eluent, the experiments were carried out for selecting the concentration of $\mathrm{HCl}$ in ethanol. For this purpose, $\mathrm{HCl}$ solution in ethanol at the concentrations between 0.5 and $2.0 \mathrm{M}$ were studied. The results (Table 3) showed that, the recovery values were increased with increase of $\mathrm{HCl}$ concentration in. After $1.0 \mathrm{M} \mathrm{HCl}$, the analytes were quantitatively recovered. Therefore, $1.0 \mathrm{M} \mathrm{HCl}$ in ethanol was selected as optimum in all subsequent experiments. The volume of $1 \mathrm{M} \mathrm{HCl}$ in ethanol was also examined between 1 and $5 \mathrm{~mL}$. The results were showed that $3 \mathrm{~mL}$ of $1.0 \mathrm{M} \mathrm{HCl}$ in ethanol was sufficient for complete desorption of the analyte ions from surface of sorbent. 
Table 2. Effect of eluent type on recovery of the analyte ions (average of 3 replicate).

\begin{tabular}{|l|c|c|}
\hline \multirow{2}{*}{$\begin{array}{l}\text { Type of eluent } \\
(1.0 \mathrm{M})\end{array}$} & \multicolumn{2}{|c|}{ Recovery (\%) } \\
\cline { 2 - 3 } & $\mathrm{Zn}(\mathrm{II})$ & $\mathrm{Cd}(\mathrm{II})$ \\
\hline $\mathrm{HCl}$ in methanol & 96 & 97 \\
\hline $\mathrm{HCl}$ in ethanol & 100 & 99 \\
\hline $\mathrm{HCl}$ in water & 89 & 83 \\
\hline $\mathrm{HNO}_{3}$ in methanol & 96 & 95 \\
\hline $\mathrm{HNO}_{3}$ in ethanol & 95 & 97 \\
\hline $\mathrm{HNO}_{3}$ in water & 85 & 78 \\
\hline $\mathrm{CH}_{3} \mathrm{COOH}$ in methanol & 58 & 62 \\
\hline $\mathrm{CH}_{3} \mathrm{COOH}$ in ethanol & 62 & 60 \\
\hline $\mathrm{CH}_{3} \mathrm{COOH}$ in water & 49 & 51 \\
\hline
\end{tabular}

Table 3. Effect of eluent concentration on recovery of analyte ions (average of 3 replicate).

\begin{tabular}{|c|c|c|}
\hline \multirow{2}{*}{ Concentration of eluent } & \multicolumn{2}{|c|}{ Recovery(\%) } \\
\cline { 2 - 3 } & $\mathrm{Zn}(\mathrm{II})$ & $\mathrm{Cd}(\mathrm{II})$ \\
\hline $\mathrm{HCl}$ in ethanol $(0.5 \mathrm{M})$ & 68 & 85 \\
\hline $\mathrm{HCl}$ in ethanol $(1.0 \mathrm{M})$ & 99 & 100 \\
\hline $\mathrm{HCl}$ in ethanol $(1.5 \mathrm{M})$ & 100 & 97 \\
\hline $\mathrm{HCl}$ in ethanol $(2.0 \mathrm{M})$ & 96 & 91 \\
\hline
\end{tabular}

\section{Effect of sample and eluent flow rate}

It is obvious that flow rate of sample is an important parameter that controls the time of analysis and affects the retention of analyte ions on the sorbent $[28,29]$. While the recovery increases with the decreasing flow rate, the preconcentration time increases [28, 29]. Therefore, to obtain the quantitative recovery and to decrease the preconcentration time, the sample flow rate was investigated in the range $0.5-5 \mathrm{~mL} \mathrm{~min}^{-1}$. It was observed that, at flow rates greater than $3 \mathrm{~mL}$ $\mathrm{min}^{-1}$, there was a decrease in the recovery of zinc and cadmium. The reason for this decrease is probably insufficient contact of the metal ions and the sorbent to reach equilibrium. Therefore, a flow rate of $2 \mathrm{~mL} \mathrm{~min}^{-1}$ was selected for subsequent experiments.

Also, the flow rate of eluent solution affects the recoveries of the analyte ions and duration of complete analysis [28, 29]. For this purpose, eluent flow rate was varied between 0.5 and 4

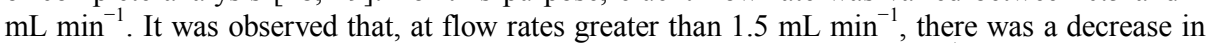
desorption of zinc and cadmium. Therefore, a flow rate of $1 \mathrm{~mL} \mathrm{~min}^{-1}$ was selected, and adjusted with a stopcock in end of the column.

\section{Effect of sample volume (breakthrough volume)}

Breakthrough volume is another parameter that influences the preconcentration factor. Breakthrough volume represents the sample volume that can be preconcentrated without loss of analyte during sample loading [29]. It is very important to get satisfactory recoveries for the analyte ions from a large volume of the sample solution. Breakthrough volume depends on the type and nature of the sorbent and also the type and concentration of sample constituents [29]. Therefore, the effect of sample volume on the retention of zinc and cadmium ions was investigated. For this purpose, 25, 100, 250, 500, 1000, 1200 and $1250 \mathrm{~mL}$ of aqueous solution, containing $1.2 \mu \mathrm{g}$ of zinc and cadmium ions; were processed according to the analytical procedure. It was observed that quantitative extraction of $\mathrm{Zn}(\mathrm{II})$ and $\mathrm{Cd}(\mathrm{II})$ ions $(>95 \%)$ was obtained up to $1200 \mathrm{~mL}$. Therefore, a preconcentration factor of 400 was obtained for zinc and cadmium ions. However, for convenience, all the experiments were carried out with $25 \mathrm{~mL}$ of the aqueous phase. 
Sorption capacity of the sorbent

Sorption capacity determines the amount of required sorbent for quantitative recovery of analytes in a given solution [29]. The sorption capacity of perlite for zinc and cadmium ions was also evaluated. In this case, a column containing $100 \mathrm{mg}$ of sorbent was used and different volumes of $10.0 \mu \mathrm{g} \mathrm{mL}^{-1}$ zinc and cadmium ions were passed through the column. The supernatant solution was collected and the presence of the analyte ions was tested by FAAS. When zinc and cadmium ions were detected in the supernatant solution, the test was stopped and the sorption capacity was calculated. The sorption capacity of perlite for zinc and cadmium was found to be 9.0 and $12.0 \mathrm{mg} \mathrm{g}^{-1}$, respectively. Both $\mathrm{Zn}$ and $\mathrm{Cd}$ are divalent; but obtained sorption capacity differs for the two ions. It may be due to factors such as absorbent chemical properties and radius of these ions.

\section{Effect of foreign ions}

In view of the high selectivity provided by flame atomic absorption spectrometry, the only interference may be attributed to the separation step. To perform this study, interference ions in different interference-to-analyte ratios were added to a solution $(25 \mathrm{~mL})$ containing $1.0 \mu \mathrm{g}$ $\mathrm{Zn}(\mathrm{II})$ and $1.0 \mu \mathrm{g} \mathrm{Cd}(\mathrm{II})$ ions and then were subjected to the analytical procedure. The tolerance limit was defined as the highest amount of foreign ions that produced an error no greater than $\pm 5 \%$ in the determination of zinc and cadmium ions. The tolerance limits of the interference ions shown in Table 4 and demonstrate that the presence of large amounts of species commonly present in water samples have no significant effect on the SPE of zinc and cadmium ions.

Table 4. Tolerance limit of foreign ions. Conditions were the same as Figure 1.

\begin{tabular}{|c|c|c|c|c|}
\hline Foreign ions & $\begin{array}{c}\text { Interference } \\
\text { /Zn(II) ratio }\end{array}$ & $\begin{array}{c}\text { Recovery } \\
\%\end{array}$ & Interference/Cd(II) ratio & Recovery \% \\
\hline $\mathrm{PO}_{4}{ }^{3-}, \mathrm{H}_{2} \mathrm{PO}_{4}^{-}, \mathrm{HPO}_{4}{ }^{2-}$ & 3000 & 95 & 3000 & 95 \\
\hline $\mathrm{CH}_{3} \mathrm{COO}^{-}$ & 2000 & 105 & 2000 & 105 \\
\hline $\mathrm{Mg}^{2+}, \mathrm{Mn}^{2+}, \mathrm{Cu}^{2+}$ & 300 & 95 & 250 & 95 \\
\hline $\mathrm{Ca}^{2+}, \mathrm{Ni}^{2+}, \mathrm{Ag}^{+}$ & 80 & 95 & 80 & 105 \\
\hline $\mathrm{Co}^{2+}, \mathrm{Pb}^{2+}$ & 100 & 95 & 150 & 95 \\
\hline $\mathrm{Fe}^{2+}, \mathrm{Fe}^{3+}$ & 100 & 95 & 100 & 95 \\
\hline $\mathrm{Al}^{3+}, \mathrm{Cr}^{3+}, \mathrm{Rh}^{3+}$ & 50 & 95 & 40 & 95 \\
\hline
\end{tabular}

\section{Calibration, precision and detection limit}

Under experimental conditions, for a sample volume of $50 \mathrm{~mL}$, calibration curves were constructed for the determination of $\mathrm{Zn}(\mathrm{II})$ and $\mathrm{Cd}(\mathrm{II})$ according to the analytical procedure. The results shown that calibration graphs were linear in the range of $0.001-0.1 \mu \mathrm{g} \mathrm{mL}^{-1}$ and $0.001-$ $0.3 \mu \mathrm{g} \mathrm{mL} \mathrm{L}^{-1}$ for $\mathrm{Zn}(\mathrm{II})$ and $\mathrm{Cd}(\mathrm{II})$, respectively. The line equations for $\mathrm{Zn}(\mathrm{II})$ and $\mathrm{Cd}(\mathrm{II})$ were $A$ $=8.6246 C+0.0032(R=0.9998)$ and $A=3.2045 C+0.0042(R=0.9991)$, respectively. In these equations, $A$ is the absorbance value, $C$ is the concentration of analyte ions $\left(\mu \mathrm{g} \mathrm{mL}^{-1}\right)$ and $\mathrm{R}$ is the correlation coefficient. The limits of detection based on three times the standard deviation of the blank $\left(3 \mathrm{~S}_{\mathrm{b}}\right)$ for $\mathrm{Zn}(\mathrm{II})$ and $\mathrm{Cd}(\mathrm{II})$ ions were 1.8 and $1.6 \mathrm{ng} \mathrm{mL}^{-1}$, respectively. Eight replicate determinations a mixture of $0.02 \mu \mathrm{g} \mathrm{mL} \mathrm{m}^{-1}$ of $\mathrm{Zn}(\mathrm{II})$ and $0.05 \mu \mathrm{g} \mathrm{mL} \mathrm{m}^{-1} \mathrm{Cd}(\mathrm{II})$ gave mean absorbances of 0.176 and 0.166 with relative standard deviations of 2.1 and $1.8 \%$, respectively. 
Analysis of water and food samples

The analytical procedure has been applied to the determination of zinc and cadmium ions in different water samples after standard addition. The results are given in Table 5.

Table 5. Determination of zinc and cadmium in water samples (average of 4 replicate \pm standard deviation)

\begin{tabular}{|c|c|c|c|}
\hline Sample & Added( $\left.\mathrm{ng} \mathrm{mL}^{-1}\right)$ & Found $^{\mathrm{a}}\left(\mathrm{ng} \mathrm{mL}^{-1}\right)$ & Recovery\% \\
\hline \multirow{4}{*}{ Tap water (Ilam) } & Zn:0.0 & $5.5 \pm 0.2$ & - \\
\hline & $\mathrm{Zn}: 10.0$ & $15.2 \pm 0.3$ & 97 \\
\hline & Cd:0.0 & $\mathrm{ND}^{\mathrm{a}}$ & - \\
\hline & Cd:10.0 & $10.2 \pm 0.3$ & 102 \\
\hline \multirow{4}{*}{ Well water (Ilam university) } & $\mathrm{Zn}: 0.0$ & $21.4 \pm 0.6$ & - \\
\hline & $\mathrm{Zn}: 10.0$ & $31.0 \pm 0.2$ & 96 \\
\hline & Cd:0.0 & $\mathrm{BLOQ}^{\mathrm{b}}$ & - \\
\hline & Cd:10.0 & $13.4 \pm 0.03$ & 103 \\
\hline \multirow{4}{*}{ Mineral water } & Zn:0.0 & $7.9 \pm 0.3$ & - \\
\hline & $\mathrm{Zn}: 10.0$ & $17.7 \pm 0.2$ & 98 \\
\hline & Cd:0.0 & ND & - \\
\hline & Cd:10.0 & $9.7 \pm 0.3$ & 97 \\
\hline
\end{tabular}

${ }^{a}$ Not detected. ${ }^{b}$ Below limit of quantitation

Also, the applicability of the proposed method was evaluated in rice, spaghetti, bread and black tea samples. For this purpose, $25.0 \mathrm{~mL}$ of the pretreated sample solution was taken individually and the analyteionswere determined by the analytical procedure. The related results are presented in Table 6.

Table 6. Determination of zinc and cadmium in food samples ( ${ }^{a}$ Average of 4 replicate \pm standard deviation).

\begin{tabular}{|c|c|c|c|}
\hline Sample & Added $\left(\mu \mathrm{g} \mathrm{g}^{-1}\right)$ & Found $^{\mathrm{a}}\left(\mu \mathrm{g} \mathrm{g}^{-1}\right)$ & Recovery (\%) \\
\hline \multirow{4}{*}{ Rice } & Zn:0.0 & $0.3 \pm 0.02$ & - \\
\hline & $\mathrm{Zn}: 10.0$ & $10.3 \pm 0.3$ & 100 \\
\hline & Cd:0.0 & $1.2 \pm 0.1$ & - \\
\hline & $\mathrm{Cd}: 10.0$ & $9.99 \pm 0.2$ & 99 \\
\hline \multirow{4}{*}{ Bread } & $\mathrm{Zn}: 0.0$ & $0.4 \pm 0.03$ & - \\
\hline & $\mathrm{Zn}: 10.0$ & $10.4 \pm 0.2$ & 100 \\
\hline & Cd:0.0 & $0.1 \pm 0.02$ & - \\
\hline & $\mathrm{Cd}: 10.0$ & $10.1 \pm 0.3$ & 100 \\
\hline \multirow{4}{*}{ Spaghetti } & $\mathrm{Zn}: 0.0$ & $4.5 \pm 0.2$ & - \\
\hline & $\mathrm{Zn}: 10.0$ & $14.6 \pm 0.2$ & 101 \\
\hline & Cd:0.0 & $1.4 \pm 0.1$ & - \\
\hline & $\mathrm{Cd}: 10.0$ & $9.99 \pm 0.1$ & 99 \\
\hline \multirow{4}{*}{ Black tea } & $\mathrm{Zn}: 0.0$ & $2.2 \pm 0.05$ & - \\
\hline & $\mathrm{Zn}: 10.0$ & $12.2 \pm 0.2$ & 100 \\
\hline & Cd:0.0 & $0.1 \pm 0.02$ & - \\
\hline & $\mathrm{Cd}: 10.0$ & $10.1 \pm 0.2$ & 100 \\
\hline
\end{tabular}

\section{Accuracy of the method}

The accuracy and applicability of the proposed method has been evaluated for the determination of $\mathrm{Zn}(\mathrm{II})$ and $\mathrm{Cd}(\mathrm{II})$ ions in National NIES No. 7 (Tea Leave) and NIES No. 1 (Pepperbush). 
Results are given in Table 7. Application of a t-test at $95 \%$ confidence level showed that there is no significant difference between the obtained results of the proposed method and certified values. These results indicate applicability of the proposed method for zinc and cadmium determination free of interference.

Table 7. Determination of zinc and cadmium in Certified Reference Materials (average of 4 replicate \pm standard deviation).

\begin{tabular}{|l|l|l|}
\hline Sample & Certified value $\left(\mu \mathrm{g} \mathrm{g}^{-1}\right)$ & Found $^{\mathrm{a}}\left(\mu \mathrm{g} \mathrm{g}^{-1}\right)$ \\
\hline NIES, No. 1 & Cd: $6.7 \pm 0.5$ & Cd: $6.6 \pm 0.2$ \\
Pepperbush & Zn: $340 \pm 20$ & $\mathrm{Zn}: 337.1 \pm 10.5$ \\
\hline NIES, No. 7 & Cd: 0.030 & BLR \\
Tea Leaves & Zn: 33 & Zn: $32.4 \pm 0.9$ \\
\hline
\end{tabular}

${ }^{\mathrm{a}}$ Below linear range.

The recovery of zinc and cadmium ions from water samples spiked with zinc and cadmium ions was also studied. For this purpose, a known volume of the stock solution was added to the sample, and then the analytical procedure was done. The results are given in Table 5. According to Table 5, the added zinc and cadmium ions can be quantitatively recovered from the water samples by the analytical procedure. These results demonstrate the applicability of the analytical procedure for zinc and cadmium ions determination in water samples.

Also, the recovery of zinc and cadmium ions from food samples spiked with zinc and cadmium ions was also studied. According to Table 6, the added zinc and cadmium ions can be quantitatively recovered from the food samples by the analytical procedure. These results demonstrate the applicability of the analytical procedure for zinc and cadmium ions determination in food samples.

Comparison with other methods

A comparison of the extraction procedure with the other reported preconcentration methods [3035] for zinc and cadmium ions are given in Table 8. Some parameters obtained were comparable to those presented by other methods described in the literature. The obtained detection limits by the extraction procedure are comparable to most of those reported in the literature.

Table 8. Comparison of the proposed procedure with the other reported procedures for preconcentration of zinc and cadmium using SPE-FAAS ("preconcentration factor; 'blimit of detection; 'breakthrough volume).

\begin{tabular}{|l|c|c|c|c|c|c|}
\hline Analyte & $\begin{array}{c}\text { Linear } \\
\text { rang } \\
\left(\mathrm{ng} \mathrm{mL} \mathrm{mL}^{-1}\right)\end{array}$ & $\begin{array}{c}\mathrm{BV}^{\mathrm{c}} \\
(\mathrm{mL})\end{array}$ & $\mathrm{PF}^{\mathrm{a}}$ & $\begin{array}{c}\mathrm{LOD}^{\mathrm{b}} \\
\left(\mathrm{ng} \mathrm{mL}^{-1}\right)\end{array}$ & $\begin{array}{c}\text { RSD } \\
(\%)\end{array}$ & Ref. \\
\hline $\mathrm{Zn}$ & ---- & 250 & 25 & 60 & $<10$ & 30 \\
\hline $\mathrm{Zn}$ & $1.0-500$ & 500 & 63 & 1.6 & 1.9 & 31 \\
\hline $\mathrm{Cd}$ & $0.1-90$ & 1800 & 360 & 0.05 & 2.4 & 32 \\
\hline $\mathrm{Cd}$ & $10-4000$ & 800 & 160 & 0.015 & - & 33 \\
\hline $\mathrm{Cd}$ & $0.01-110$ & 300 & 300 & 1.2 & 4.7 & 34 \\
\hline $\mathrm{Cd}$ & $1.0-20$ & 500 & 250 & 0.2 & 20 & 35 \\
\hline $\mathrm{Zn}$ & $1.0-100$ & 1200 & 400 & 1.8 & 2.1 & This work \\
\hline $\mathrm{Cd}$ & $1.0-300$ & 1200 & 400 & 1.6 & 1.8 & \\
\hline
\end{tabular}




\section{CONCLUSION}

This paper proposes a method for the preconcentration and determination of trace amounts of zinc and cadmium by using perlite as sorbent material combined with FAAS. The results showed that perlite as a new sorbent has high capacity, good stability and fast adsorption and desorption kinetics. This method is characterized with simplicity, rapidity, reliability, safety and low cost, and is suitable for the determination of trace amounts of zinc and cadmium ions in water and food samples. The main advantages of this procedure are (i) the proposed method is sensitive and selective, (ii) avoidance of channeling effects that are common in packed beds and (iii) good enrichment factor (400) can be achieved.

\section{REFERENCES}

1. Melek, E.; Tuzen, M.; Soylak, M. Anal. Chim. Acta 2006, 578, 213.

2. Shah, A.Q.; Kazi, T.G.; Jamali, M.K.; Arain, M.B.; Afridi, H.I.; Jalbani, N.; Kandhro ,G.A.; Baig, J.A.; Sarfraz, R.A.; Ansari, R. Food Chem. 2009, 113, 1351.

3. Kazi, T.G.; Arain, M.B.; Jamali, M.K.; Afridi, H.I.;Jalbani, N.;Sarfraz, R.A.; Ansar, R. J. Hazard. Mater. 2009, 161, 1391.

4. Diaz-Perez, M.; Aboal-Somoza, M.; Bermejo-Barrera, P.; Bermejo-Barrera, A. Cent. Eur. J. Chem. 2008, 6, 520.

5. Eren, E.; Afsin, B.; Onal, Y. J. Hazard. Mater. 2009, 161, 677.

6. Aranda, P.R.; Gil, R.A.; Moyano, S.; De Vito, I.; Martinez, L.D. J. Hazard. Mater. 2009, $161,1399$.

7. Kong, X.; Jia, Q.; Zhou, W. Microchem. J. 2007, 87, 132.

8. Madrakian, T.; Zolfigol, M.A.; Solgi, M. J. Hazard. Mater. 2008, 160, 468.

9. Burham, N.; Azeem, S.A.; El-Shahat, M.F. Cent. Eur. J. Chem. 2009, 7, 945.

10. Mohammadi, S.Z.; Karimi, M.A.; Hamidian, H.; Baghelani, Y.M.; Karimzadeh, L. J. Chil. Chem. Soc. 2011, 56, 682.

11. Mohammadi, S.Z.; Afzali, D.; Taher, M.A.; Baghelani, Y.M. Talanta 2009, 80, 875.

12. Mohammadi, S.Z.; Shamspur, T.; Afzali, D.; Taher, M.A.; Baghelani, Y.M. Arab. J. Chem. (in press), DOI: 10.1016/j.arabic.2011.07.003.

13. Silva, E.L.; Roldan, P.S. J. Hazard. Mater. 2009, 161, 142.

14. Araneda, C.; Fonseca, C.; Sapag, J.; Basualto, J.; Yazdani-Pedram, M.; Kondo, K.; Kamio, E.; Valenzuela, F. Sep. Purif. Technol. 2008, 63, 517.

15. Xie, F.; Lin, X.; Wu, X.; Xie, Z. Talanta 2008, 74, 836.

16. Yamini, Y.; Haji Hosseini, M.; Morsali, A. Microchim. Acta 2004, 146, 67.

17. Ghaedi, M.; Niknam, E. Bull. Chem. Soc. Ethiop. 2010, 24, 11.

18. Faraji, M.; Yamini, Y.; Saleh, A.; Rezaee, M.; Ghambarian, M.; Hassani, R. Anal. Chim. Acta 2010, 659, 172.

19. Shokooh Saljooghi, A.; Fatemi, S.J.; Afzali, D. Bull. Chem. Soc. Ethiop. 2010, 24, 127.

20. Rofouei, M.K.; Payehghadr, M.; Shamsipur, M.; Ahmadalinezhad, A. J. Hazard. Mater. 2009, 168, 1187.

21. Shamspur, T. Bull. Chem. Soc. Ethiop. 2012, 26, 19.

22. Mohammadi, S.Z.; Shamspur, T.; Baghelani, Y.M. Bull. Chem. Soc. Ethiop. 2013, 27, 161.

23. Shariati, S.H.; Yamini,Y.; Faraji, M.; Saleh, A. Microchim. Acta 2009, 165, 65.

24. Duran, A.; Soylak, M.; Tuncel, S.A. J. Hazard. Mater. 2008, 155, 114.

25. Soylak, M.; Karatepe, A.U.; Elçi, L.; Doğan, M. Turk. J. Chem. 2003, 27, 235.

26. Elci, L.; Soylak, M.; Dogan, M. Fresen. J. Anal. Chem. 1992, 342, 175.

27. Bulut, V.N.; Gundogdu, A.; Duran, C.; Senturk, H.B.; Soylak, M.; Elci, L.; Tufekci, M. J. Hazard. Mater. 2007, 146, 155.

28. Mohammadi, S.Z.; Afzali, D.; Pourtalebi, D. Cent. Eur. J. Chem. 2010, 8, 662.

Bull. Chem. Soc. Ethiop. 2016, 30(2) 
29. Shamspur, T.; Mostafavi, A. J. Hazard. Mater. 2009, 168, 1548.

30. Vellaichamy, S.; Palanivelu, K. J. Hazard. Mater. 2011, 185, 1131.

31. Ghaedi, M.; Tavalli, H.; Shokrollahi, A.; Zahedi, M.; Motazerozohori, M.; Soylak, M. J. Hazard. Mater. 2009, 166, 1441.

32. Behbahani, M.; Bagheri, A.; Amini, M.M.; Sadeghi, O.; Salarian, M.; Najafi, F.; Taghizadeh, M. Food Chem. 2013, 141, 48.

33. Malekpoura, A.; Hajialigol, S.; Taher, M.A. J. Hazard. Mater. 2009, 172, 229.

34. Yang, G.; Fen, W.; Lei, C.H.; Xiao, W.; Suna, H. J. Hazard. Mater. 2009, 162, 44.

35. Parham, H.; Pourreza, N.; Rahbar, N. J. Hazard. Mater. 2009, 163, 588. 